\title{
Adolescens och estetisk praxis
}

\author{
OVE SERNHEDE
}

\begin{abstract}
Med utgaingspunkt i psykoanalys och lingvistisk symbolteori diskuterar Ove Sernhede hur det egna skapandet griper in i adolescensutvecklingen. Han undersöker faktorer som kan tänkas ligga bakom att det just är musiken som hamnat i centrum för ungdomskulturen?
\end{abstract}

Friställd från traditionens makt tvingas individen i det moderna samhället $i$ allt högre grad att framställa och skapa sig själv. En konsekvens av detta är bland annat att kulturen blivit en allt mer avgörande dimension av moderniteten. En rad samtida samhälls- och kulturteoretiker har hävdat att den under senare decennier allt mer expanderande konsumtions- och mediekulturen är av central betydelse för såväl individens identitet som för samhällsutvecklingen. Flödet av framför allt medierade bilder och musik har tvingat individen att utveckla en känslighet när det gäller att läsa och förhålla sig till tecken, symboler och stilar. Det finns de som hävdar att vi numera lever i en nestetisk hallucination av verkligheten" (Baudrillard 1985/1987). Konsumtionen har också, på ett nytt sätt, blivit en del av den kulturel-

Ove Sernhede är leg. psykoterapeut och lektor vid institutionen för socialt arbete, Göteborgs universitet och verksam vid Forum för Studiet av SamtidsKulturen. Han har gett ut en rad arbeten med utgångspunkt i ungdomsforskning, senast Ungdomskulturen och de Andra (Daidalos 1996). la nivån. Kläder, heminredning, kroppsbyggande och andra aspekter av individens stil har blivit allt mer betydelsefulla för den individuella identiteten. Intresset för kultur och symboliska aspekter av den moderna människans livsformer avspeglar sig också i den vetenskapliga världen. Kultur är inte längre ett forskningsfält med exklusivitet för humaniora. Under 1980-talet har kulturstudier och kulturteori kommit att inta en allt mer central roll inom flera samhällsvetenskaper (se t.ex. Grossberg m.fl. 1992, Featherstone 1994).

Sedan 1960-talet har mötet mellan populärkultur och avantgardkultur också gjort det allt svårare att upprätthålla den gamla demarkationslinjen mellan vad som är lågt och vad som är högt i kulturen. ${ }^{1}$ Den respektlöshet i relation till konsten som tidigare var förbehållet det modernistiska av-

1 Fornäs (1992 s 26) menar att „All kultur tenderar att medialiseras i senmoderniteten[...] Triangeln elitkultur - populärkultur - folklig kultur kan därför ses som en övergångsform, då allt inordnas under det populära i senkapitalismen«. 
antgardets konstnärliga praxis har, inte minst genom ungdomskulturens genrerblandningar, trängt ut i breda grupper (Ziehe 1988, Drotner 1991). I reproduktionsåldern (Benjamin 1969) har konsten avmystifierats och ses inte längre som ett besjälat väsen, den är inte längre bärare av absoluta eller högre värden och svävar inte heller ovanför samhälleliga villkor.

Dessa aspekter har relevans för och ger kontext åt denna artikel, som diskuterar psykologiska aspekter av den 'nya ungdomens' intresse för det kulturella fältet $\mathrm{i}$ allmänhet och det egna skapandet i synnerhet. Det ter sig som om egen kulturell praktik idag blivit ett "måste» på ett helt annat sätt än tidigare. ${ }^{2}$ I det senmoderna samhället befinner sig de traditionella identitetsmönstren vad gäller klass, kön och etnicitet i upplösning, gamla trossystem och ideologier spelar inte längre den roll de tidigare gjorde. Detta har lett till att identitet idag, med den polsk-brittiske sociologen Zygmunt Bauman, utgör det nav runt vilket den moderna människans villkor roterar. Antropologen

2 Min förståelse av kultur är främst relaterad till symboliska aspekter av mänskliga livsformer, detta innebär att kulturbegreppet både har med medvetande och kommunikation att göra. Detta betyder en insnävning i jämförelse med antropologins breda och närmast allomfattande kulturförståelse. I jämförelse med den »rena» estetikens högst begränsade kulturbegrepp, där kultur ses som liktydigt med teater, litteratur, musik osv.. är det dock en utvidgning. Kanske kan man se detta kulturbegrepp med fokus på symboliska och kommunikativa aspekter av mänskligt som en brygga mellan det antropologiska och det estetiska kulturbegreppet. Se Fornäs (1992) för en utförlig diskussion om kulturbegreppet, se också Ehn/Löfgren (1982).
Jonathan Friedman (1994 s 22) menar att moderniteten djupast sett består $\mathrm{i}$ »att alteriteten framträder som ett stadigvarande tillstånd där jaget aldrig fixeras, där det alltid finns andra möjliga identiteter och existenser".

Den osäkerhet och ambivalens som genomsyrar vardagen i senmoderniteten har gjort det allt nödvändigare för oss att förstå, tolka och skapa oss själva och vår värld. Vår upptagenhet av symboler, stilar och kulturella koder har, liksom suget efter det egna skapandet, sin grund i att vi i dessa sammanhang kan utforska, forma och skapa oss själva, finna en form av säkerhet och skapa mening. Det är mot denna bakgrund inte svårt att förstå varför det estetiska fältet blivit så betydelsefullt just för de unga. Förutom att de lever i moderniteten befinner de sig också i en utvecklingsfas (adolescensen) där osäkerhet, identitetsarbete och sökandet efter mening är nära nog oundvikliga aspekter av livsvillkoren.

Dessutom, i ett samhälle där systemens mål-medel rationalitet tränger in i och koloniserar livsområden där den inte hör hemma, tenderar kultur och estetisk verksamhet att bli "till reservat för tillfredsställelsen av de behov som i det borgerliga samhällets materiella livsprocesser så att säga blivit illegala». Här kan också "längtan efter den lyckliga, kommunikativa erfarenhet som är befriad från målrationalitetens imperativ," komma till uttryck (Habermas 1973/1975 s 88).

Ungdomskulturen har under de två senaste decennierna visat upp ett accentuerat intresse för egen kulturproduktion. Med punken skedde ett språng i denna utveckling, egen estetisk verksamhet kom nu att 
inta en allt viktigare position i kulturellt aktiva ungdomars liv. Genom att kritisera rockens utveckling till industri kom punken - inte minst i Sverige - att skapa en »spelasjälv-våg" som uppenbarligen svarade mot behov hos stora delar av den moderna ungdomen. Punken innebar en massmobilisering runt det egna skapandet. Detta gällde i synnerhet musiken, som under 80-talet utvecklades närmast explosionsartat. Rockmusiken blev i Sverige under detta decennium en verklig massrörelse bland de unga. Antalet aktiva utövare expanderade och musikutövandet bland unga nådde en omfattning som gör att denna verksamhet idag är att jämföra med antalet aktiva inom sport och idrott. Rock- och populärmusiklyssnandet är också ungdomars största fritidsintresse. ${ }^{3}$ Den bild som ofta tecknas i massmedierna av ungdomars närmast besatta relation till musik är inte helt missvisande. Musiken har, bland annat av orsaker som skall diskuteras i denna text, en centrala ställning i moderna ungdomars liv. Även om musiken intar en särställning är trenden mot stigande intresse för egenproduktion också tydliga inom dans, teater, film, video, bildskapande (Czaplicka 1987, Ziehe 1989, Drotner 1991).

3 Statens ungdomsråd intervjuade 1990 omkring 1000 ungdomar $i$ åldern $16-25$ år, 94 procent ansåg sig vara ganska eller mycket intresserade av musik (siffran var den samma för båda könen), 71 procent uppgav att de var ganska eller mycket intresserade av idrott. Ca 20 procent av såväl pojkarna som flickorna spelade själva, se Uppväxtvillkor nr 4-5 1991. En uppföljande undersökning från 1992 (som Bjurström (1993) hänvisar till) visar att 10 procent av pojkarna i åldern 16-25 år spelade i band.
Uppenbart är att det ligger en rad olika faktorer bakom att ungas fritid $i$ allt större utsträckning kännetecknas av ett ökat engagemang för det egna skapandet. Min utgångspunkt för denna text är att med hjälp av psykoanalys och symbolteori undersöka vilka funktioner kulturella uttrycksformer kan tänkas ha för dagens unga. Hur griper adolescensutvecklingen in i det egna skapandet? Hur kommer det sig att just musiken hamnat i centrum för de ungas estetiska praxis? ${ }^{4}$ Rockmusiken, som är föremål för intresset i denna text, är som bekant dominerad av unga män. Därav följer att diskussionen i första hand är relaterad till pojkar,

4 När jag i denna text använder begreppet estetisk praxis avser jag inte enbart de olika former av estetisk framställning och egen kultur produktion som vi normalt förknippar med de olika konstarterna, dvs. att spela musik, teater, skriva lyrik osv.. Estetisk praxis är en verksamheter som äger rum i av samhället definierade institutioner såväl som i. de sammanhang där människor lever sina liv. Men det finns också i alla människors vardagsliv; i vuxnas sätt att använda medierna, i ungas stilproduktion, i barns lekar osv. estetiska aspekter. Även reception av kulturprodukter, från konstutställning till tv-tittande, kan ju sägas innehålla aspekter av estetisk praxis eftersom denna verksamhet aldrig är "passiv" utan alltid inbegripen $\mathrm{i}$ individens produktion av mening och identitet. Vanligtvis är begreppet estetisk praxis, estetisk produktion begränsat till de framställande konstarterna. I min framställning innefattar begreppet alla de handlingar och produkter människor skapar i den symboliska kommunikation där estetiska aspekter är framträdande; gitarrspelande är liksom skapande av klädstilar, frisyrer, raggarnas bilbyggen osv. att betrakta som estetisk praxis - dvs. som kommunikativa, kulturella uttryck med konstnärliga aspekter. Jfr Hartwig (1980), Drotner (1991) och Fornäs (1992). 
men det innebär inte att den grundläggande tankefiguren enbart skulle vara giltig i förhållande till manlig adolescens- och identitetsutveckling.

\section{Adolescens, identitet och kultur}

Utgångspunkt för min diskussion är musiken. Den intar en central position i ungdomskulturen och har, menar jag, en betydelsefull roll i det adolescenta identitetsarbetet. I Av drömmar väver man har jag, mot bakgrund av mina erfarenheter från socialpedagogiskt arbete med ungdom visat hur en grupp ungdomar använde sig av rockmusik för att bygga identitet, att bli Någon. Med utgångspunkt i den egna självframställningen skapade dessa unga mening och livssammanhang. Musiken blev deras språk och hävstång i ett revanschartat möte med samhället. Det kollektiva spelandet startade läroprocesser som ledde till ökad självinsikt och socialt, kulturellt och politiskt uppvaknande. I Under rocken har jag, tillsammans med Johan Fornäs och Ulf Lindberg, studerat hur rockmusicerandet utgör en aspekt av i första hand unga mäns socialisation och därigenom griper in i adolescensens identitetsarbete.

Begreppet identitet är varken entydigt eller enkelt att handskas med. Oftast när det diskuteras i relation till ungdomskultur kopplas det ihop med begreppet stil, dvs. punk, hip-hop osv. Men stil relaterar bara till en aspekt (socio-kulturella) av identiteten, stilen är ett sätt att »utåt» markera identitet. Vad jag vill trycka på i detta sammanahang, där adolescens och eget skapande står i förgrunden, är att identitetsbegreppet också vätter "inåt" - mot individens inre psykiska strukturer. Med psykoanalytisk terminologi skulle man kunna säga att identiteten är en funktion hos jaget som knyter ihop den inre och den yttre världen liksom den för samman historia och nutid. ${ }^{5}$ Den av individen upplevda egna identiteten är något som växer fram i en väv av psykiska och socio-kulturella processer.

Ungdomskulturens symbol- och kommunikationssystem har som del i ett socialt teckensystem uppenbara funktioner att för omvärlden visa vem man är eller vem man skulle vilja vara. ${ }^{6}$ Men ungdomskulturens

5 Börjeson (1974) diskuterar psykoanalytiska aspekter av identiteten med utgångspunkt i denna bestämning. Fornäs (1991) talar om identitet som en komplex struktur av flera växelverkande aspekter. En "fysisk eller institutionell" aspekt av identiteten rör de objektiva, yttre villkor som omger en individ, t.ex. de ekonomiska kategorier som placerar individen i en kontext vare sig han är medveten om det eller inte. Dessutom finns en intersubjektiv aspekt som i sin tur kan delas upp i sociala och kulturella underaspekter. Den sociala sidan är relaterad till sociala normer och relationer medan den kulturella sidan rör de bilder och symboler vi använder för att ge uttryck för identitet. Därutöver finns en inre psykisk aspekt som är unik och egen för varje enskild individ, en jaguppfattning som också förmår att hålla ihop individen som en historisk varelse.

6 Om rockmusik och -smak som symboliskt kapital se Trondman (1989) och Bjurström (1993). Dessa viktiga kultursociologiska studier diskuterar, bland annat med utgångspunkt i Bourdieu, de symboliska uttryckens relation till sociala förhållanden. Min diskussion i denna text begränsar sig till att behandla den estetiska produktionens betydelse och funktioner i relation till adolescensteori. I Under Rocken 
icke-verbalt språkliga uttryck har också funktioner som griper in i de »inre» psykiska omstruktureringsprocesser som är kännetecknande för adolescensen. När jag nu uppmärksammar den estetiska självframställningen, och då inte minst den i ungdomskulturen så betydelsefulla musiken, är det för att den besitter egenskaper som också gör det möjligt för individen att orientera sig i och lära känna sitt eget inre psykiska landskap. En aspekt som är nog så viktig i just adolescensen.

I Under rocken ställer vi oss frågan om inte adolescensen i det moderna samhället kan ses som en wandra språktillägnelse» eller födelse. ${ }^{7}$ Det lilla barnet föds som social eller samhällelig varelse genom inträdet i det verbala språket. Denna första språktillägnelse har delvis sin drivkraft i barnets behov att hantera separationen från modern. Kanske kan man på ett motsvarande sätt tala om att ungdomar $i$ vår tid träder in i ungdomskulturens många icke-verbala språk för att återigen hantera en separation från familjen och slutgiltigt träda in $i$ vuxenlivet. Att lämna barndomen bakom sig är på många sätt en smärtsam process. Än en gång, som under det lilla barnets första individuationsprocess, handlar det om att symbolisera en förlust samt att hantera den aggression i relation till föräldrarna som måste till för att frigörelse skall bli möjlig. Detta aktualiserar de aspekter av adolescen-

finns naturligtvis kultursociologiska reflektioner, bland annat med utgångspunkt i samma teoretiska referenser som Trondman och Bjurström.

7 Inspirerade av bland andra Lacan (1966/1989), Lorenzer (1972/1975), Kristeva (1974/1978) och Wirth (1984). sen som rör vid dess pånyttfödda "depressiva position". Det finns också i ungdomars intresse för estetisk självframställning aspekter som knyter an till denna positions sorge- och reparationsarbete. ${ }^{8}$

En annan aspekt av denna mandra språktillägnelse» är hur ungdomskulturens ickeverbalt språkliga aspekter erbjuder symboliska uttrycksformer som bryter mot den verbala rationalitetens $i$ adolescensen och $i$ senmoderniteten alltmer problematiska dominans. Kunskap och språk har allt mer kommit att inordnas i samhällets instrumentellt definierade nyttosammanhang. Skola och yrkesliv ger allt mindre utrymme àt de upplevelser, känslor och behov som inte låter sig inpassas i den rådande målmedel-rationaliteten. I denna situation söker sig ungdomar mot musik, bild och kroppslig expressivitet som alternativ till och för att utmana ordets hegemoni på kommunikationens område. ${ }^{9}$ En aspekt av hemligheten med rockmusikens fascinationskraft utgörs också av dess förmåga att tillhandahålla ett språk där upplevelser som är utträngda från det dominerande språket kan artikuleras. Rockmusiken bär alltså utifrån detta perspektiv på en potential att exponera sinnlighet, utlevelse och kropp. Parallellt med denna offensiva funktion finns

8 I Under Rocken diskuteras denna aspekt i analysen av subjektiva drivkrafter bakom Kurres rockspelande. Se också Kristeva (1990).

9 Måhända är den klyfta eller motsättning som ibland målas upp mellan å ena sidan ordmedier och å andra sidan musik- och bildmedier inte nödvändig. Fornäs (1992) liksom Drotner (1991) pekar på att läsandet och det egna skrivandet inte blivit mindre viktigt för att icke-diskursiva uttrycksformer fått större betydelse. 
rockmusiken också som reservat för de ungdomligt regressiva strävanden som söker undkomma den samhälleliga realitetens kravfullhet, som i kamratgruppens trygghet ger uttryck för sina narcissistiska behov.

I den diskussion och ungdomskulturforskning som intresserat sig för ungas kulturella uttryck (rockmusik i synnerhet) har framför allt de i ungdomskulturen rikligt förekommande narcissistiska upplevelseformerna och regressiva undflyende beteendemönster relaterats till framväxten av en ny narcissistisk behovsstruktur. ${ }^{10}$ Mot denna bakgrund har ungas fascination och dragning till rock relaterats till musikens förmåga att via en överladdning av sinnesorganen involvera såväl kropp som »själ«. Det jag som i vardagen är hotat av fragmentering och osäkerhet kan i musikens tid och rum bli en hel varelse. Rockkonserten (likväl som det egna spelandet) kan ses som en stotalupplevelse« där gränserna mellan det egna jaget och omgivningen är upplöst - vilket då skulle svara mot djupt liggande narcissistiska behov. Samtidigt är dessa upplevelseformer uttryck för en del av den egna personligheten som utgör annan realitet, idet ickeidentiskas tagg mot det allmänt vedertagna" (Nørregard m.fl. 1982). Återknytandet till förspråklig sammansmältning och jämvikt kan därigenom också ses som en möjlig reservoar för kritik av den förhärskande rationaliteten i samhället. ${ }^{11}$

När vi iakttar hur ungdomars omedvetna

10 Ziehe (1975), Nørregaard m.fl.(1982), Nielsen (1984), Sernhede (1984), Fornäs, Lindberg, Sernhede (1988), Fornäs (1991) är några exempel.

11 För vidare läsning om ungdomskulturens former för narcissistisk uppladdning av självet, de nya önskningar, och deras strävan att tillfredsställa dessa, delvis är knutna till åkallandet av upplevelser vilka kan relateras till ett jagtillstånd som grundats före inträdet $\mathrm{i}$ språket så innebär detta att vi har att göra med narcisstiskt infärgade önskningar eller behov. Narcissistiska framträdelseformer har sedan 1960-talet otvivelaktigt blivit allt tydligare i ungdomskulturen och utan tvekan har grundläggande villkor för subjektets tidigaste konstitutionsprocesser genomgått förändringar. Min uppfattning är ändå att dessa fenomen i för ringa omfattning diskuterats i relation till den narcissism som utgör en så viktig aspekt av adolescensen. I linje med den i psykoanalysen förhärskande barndomsdeterminismen har dessa fenomen i första hand diskuterats mot bakgrund av teorin om en generell narcissistisk behovsstruktur med rötter i en arkaisk modersbindning. ${ }^{12}$ De narcissistiska framträdelseformer som ungdomskulturen är så

försvarsstrukturer som utvecklas i kamratgruppen osv. se t.ex. Sernhede (1984).

12 Se sociologen Thomas Johansson (1994) för en intressant diskussion där han med utgångspunkt i Giddens, Featherstone, Goffman och andra vill skapa en socialpsykologisk ansats för att förstå narcissistiska framträdelseformer i det moderna samhället. Johansson är liksom jag kritisk mot att ensidigt förklara dessa tendenser mot bakgrund av den primära narcissmens morbarnsymbios. Hans förslag om att lyfta fram barnets och den vuxnes hela sociala och kulturella miljö har många beröringspunkter med Ziehes diskussion om "narcissismen uppifrån" (Ziehe, 1982/1983, 1984). Min diskussion har inga ambitioner att på detta sätt öppna narcissismbegreppet mot sociologi utan vill enbart lyfta fram adolescensfasens "egen " men $i$ ungdomsforskningen förbisedda narcissismutveckling. I Under Rocken diskuteras adoles- 
rik på måste i större utsträckning förstås i ljuset av den narcissism som är kännetecknande för adolescensen. Denna har också relevans för min diskussion om det egna skapandet i adolescensen. Av denna anledning vill jag lyfta fram några betydelsefulla aspekter av adolescensutvecklingen, dess narcissism och regressionsprocesser.

\section{Adolescens och regression i jagets tjänst}

Adolescensen innebär, utifrån den psykoanalytiska horisont vi här diskuterar, en uppladdning av hela den tidiga barndomens objektrelationer. ${ }^{13}$ Den kännetecknas av regressionsprocesser som söker sig tillbaka till

censteori i relation till modernitet och ungdomskultur. Trots detta är distinktionerna mellan adolescent narcissism och den narcissism som vi relaterade till som mer generella socialisationsförändringar inte så utvecklad som jag skulle önska. Presentationen av Ziehes narcissismteori i Sernhede (1984) saknar i princip denna distinktion.

13 Adolescens innefattar utöver den psykosexuellt och emotionellt/motivationsmässiga omstruktureringsdimension vi koncentrerar oss på i detta sammanhang också av utvecklandet av interaktiv kompetens, av kognitiva och moraliska utecklingsprocesser $\mathrm{m} \mathrm{m}$, alla dessa aspekter av adolescensen kan naturligtvis inte frikopplas från varandra utan måste snarare ses som inflätade i varandra i en komplex utvecklingsdynamik. Se Blos (1962), Habermas (1974/1990), Mangs \& Martell (1982). Därutöver kännetecknas tonårstiden också av puberteten, den kroppsligt-fysiologiska utvecklingen, vilken självklart också griper in i och »sätter" sina villkor för de psykologiska utvecklingsprocesserna. För denna sida av tonårsutvecklingen se Kaplan (1984/1987). redan välprövade modeller för konfliktlösning men också av en utveckling som längs en annan dimension integrerar driftstruktur, moralisk utveckling och kognitiv växt till en ny identitet. Dessa karakteristika gäller för den klassiska såväl som för den i vår tid nya, mer öppna adolescensutveckling som jag kommer till längre fram. Narcissistiska upplevelseformer diskuteras ofta i samband med adolescens, de utgör exempel på den typ av kontrollerade regressioner som adolescenstiden är rik på. Genom regressionen upprättas en för jagutvecklingen nödvändig kontakt med det omedvetna, tidigare utvecklingsskeden och primitivare former av tänkande. ${ }^{14}$ För den vuxne individen såväl som för latensbarnet ses ofrivilliga regressioner som uttryck för olika former av "störningu. Individen brottas med icke-integrerade psykiska funktioner. Adolescensen är den enda period i livet då regression är önskvärd, regressionen är en förutsättning för framåtskridande och växt.

Peter Blos (1962), den psykoanalytiskt orienterade författare som skrivit mest och utförligast om adolescensen, gör i sitt klassiska arbete en fasindelning av adolescen-

14 Freud (1900/1959 s 327) och psykoanalysen skiljer på „tre arter av regression: a) en topisk (lokal) [som i t.ex. drömmen upprättar kontakt med det omedvetna, min anm.] b) en temporal (tidsmässig) i den mån det gäller att återgå till äldre psykiska bildningar och c) en formell, då primitiva uttrycks- och framställningssätt ersätter de vanliga. Men alla tre slagen av regression är i grunden en och samma och förenas i de flesta fall, ty det i tiden äldre är också det formellt mer primitiva och det som i det topiska schemat ligger närmare varseblivningssidan«. 
sen..$^{15}$ Centralt i denna fasindelning står "adolescence proper", eller den egentliga adolescensen. Känslolivet blir nu mer intensifierat och det egna spirande självet laddas upp som en konsekvens av att de inre representationerna av föräldrarna avladdas och töms på energi. Denna adolescenta form av narcissism - som består i att individen nu istället överladdar de egna sinnesorganen, kroppen och självet som helhet - måste också ses som ett sätt att försvara sig mot de depersonaliseringstendenser som är en konsekvens av den nu så bräckliga självkänslan.

15 Den första för-adolescenta-fasen utgörs av en reaktivering av pre-genitala (omedvetna incestuösa) fantasier och driftsyttringar. Den kastrationsångest som förde den oidipala situationen till ända kommer nu att framträda med ny styrka och tvingar pojken till att söka sig mot sitt eget kön. Den deskriptiva psykologin betraktar också denna fas som gängstadiet. Ett homosexuellt färgat försvar mot den arkaiska modersrepresentationen gör dessa exklusiva pojkgemenskaper till en slags avvärjnings- eller försvarsstrategier som odlar ett avvisande av allt kvinnligt. I nästa fas, den tidiga adolescensen, börjar de inre föräldrarepresentationerna avladdas och det $\mathrm{i}$ latensen riktningsgivande överjaget mister något av sin styrka. Värden och moralfrågor börjar bli mer självständiga i förhållande till föräldrarna, likaså växer känslan och behovet av känslomässig lösgörelse i förhållande till dem. Samtidigt skapar denna utveckling känslor av tomhet och ensamhet som leder individen mot ett än starkare engagemang i kamratgruppen. Den psykiska enegri som tidigare var knutet till föräldrarna riktas nu mot idealiserade kamrater och idoler men kommer också allt mer att riktas mot den egna personen, en upptagenhet som förstärks i den följande fas som går under beteckningen den egentliga adolescensen (adolescence proper).
Ett försvar för det svaga jaget består i att fantasiliv och dagdrömmar nu intar en central plats i den unges liv. Den laddning. som upphettningen av tankar, fantasier och själviakttagelse bär på ger också möjlighet till koncentration och hängivelse som kommer väl till pass i de estetiska processer som nu får en påtaglig fascinationskraft och på ett nytt sätt framstår som ett behov.

The creative productivity thus represents an effort to accomplish urgent tasks of internal transformations. The cathexis of thought and introspection permits a concentration and dedication to the creative process of thought and imagery that is almost unknown before or after in the life the average individual. The creativity in adolescence enhances infatuation with the self; it is often accompanied by excitement and carries the conviction of being a chosen and special person (Blos $1962 \mathrm{~s}$ 126).

Självframställning i musik, bild, poesi, dagboksskrivande osv. ger narcissistisk tillfredsställelse samtidigt som den externaliserar aspekter av den inre världen, den riktar sig ut mot andra och stärker självkänslan. ${ }^{16}$ En viktig aspekt av de skapande processerna är dess förmåga att ge utrymme åt

16 Blos (1962s 126) anger fyra punkter för den skapande processen " 1) it is highly self-centered, that is narcissistisc; 2) it is subordinated to the limitations of an artistic medium, and consequently is partially reality oriented; 3 ) it operates within the modality of 'giving life to a new existence', the self; 4) it constitutes a communication with the environment and is, therefore, partially object related". Freud talar om överjaget som oidipalsituationens arvtagare, Blos menar på ett motsvarande sätt att självet, en mer helt integrerad personlighet av kropp och själ, är adolescensens arvtagare. 
regressionens tillbakagripande rörelser. Blos trycker upprepade gånger på hur viktig regressionen är för den adolescenta individuationsprocessen.

The task of the pshychic restructuring by regression represents the most formidable psychic work of adolescent [...] only through drive and ego regression can the adolescent task be fullfilled. (Blos 1967 s 171).

Blos tar hjälp av Nietzsche för att belysa vad han menar "They say he is going backward, indeed he is, because he attempts to jump" (Blos 1962 s 92). Det är alltså bara via den unges förnyade kontakt med infantila och förspråkliga konflikter och upplevelsenivår som adolescensens inneboende möjligheter kan realiseras. Att fullgöra de fysiologiska och sociala sidorna av adolescensen är inte tillräckligt, utan de psykologiska regressionsprocessernas möte med och bearbetning av infantila försvar, konflikter och bindningar blir inte adolescensen avslutad

I might say that puberty is an act of nature and adolescens is an act of man. This statement emphasizes the fact that neither the completion of physical growth, nor the attainment of sexual functioning, nor the social role of economic self-support are, by and in themselves, reliable for the termination of the adolescent process. (Blos 1979 s 405-6)

Regressionens "resa tillbaka» kan ses som en inre resocialisering där den tidiga barndomens starka och motstridiga känslor åter aktiveras och bearbetas för att framväxten av en ny psykisk struktur skall bli möjlig. Ernst Kris (1952) talar om samma processer i termer av "funktionell regression" och "regression $i$ jagets tjänst «. ${ }^{17}$
"Adolescence proper " befinner sig mitt i den process där banden bakåt på väg att lösas upp samtidigt som den nya personlighetsformationens självstrukturer ännu inte funnit sina konturer. Det är till denna fas' intensifierade narcissism Blos i första hand förlägger fantasi, kreativitet och den skapande verksamheten. Skapandet är alltså inte bara relaterat till regression utan också knutet till strävan att integrera de förhopp-

17 «Adolescence proper« innebär också början på en orientering mot det andra könet, men det är ännu inte frågan om ett verkligt hetrosexuellt objektval utan om i fantasin grundade narcisstiska objektval som används för att stabilisera ett svagt fungerande jag. Begäret att fullt ut tillhöra någon annan är en kvalitativt ny känsla jämfört med barndomens förälskelser. Oidipuskomplexets återkomst $i$ adolescensen innebär för pojken bland annat att han måste få bukt med sina feminina tendenser eller rester, dvs. den negativa oidipala situationen, ofta leder detta till att han tar sin tillflykt till häftiga maskulina stereotyper för att överbevisa sig själv om sin egen manlighet. I sen-adolescensen kommer strävan mot det heterosexuella objektvalet att inta en central plats, de pre-genitala driftsrörelserna underordnas den genitala sexualiteten, en mer differentierad jagstruktur skapas och efterhand växer ett integrerat jag fram som kan fungera som en instans för den nödvändiga sublimering som omvandlar den psykiska enerigin till socialt accepterade och statusskapande projekt. Adolescensen består enligt Blos (1962) av två huvudtema; oidipuskomplexets återkomst och frigörelsen från de primära kärleksobjekten.

Adolescensen handlar utifrån dessa tema om objektförlust och objektfinnande dvs. om att lära sig sörja och att kunna bli förälskad. Att ge avkall på de oidipala föräldrarna leder till upplevelser av sorg, tomhet och förlust som måste hanteras. För att kunna bli förälskad måste individen utveckla ett själv med kapacitet till objektkärlek. 
ningar och nyorienterande ideal som den unge bär på. Ingen annan period visar upp samma förmåga att lustfyllt röra sig mellan medvetet och omedvetet, mellan sekundär och primärprocesser, mellan barndomens konflikter och samtidens krav och ingen annan period visar upp ett så mångfasetterat skapande.

\section{Diskursiva och presentativa symboler}

Den adolescenta narcissismen har alltså sin grund $i$ att den unge börjat lösa upp bindningarna till de inre föräldrarepresentationerna men han/hon har ännu inte utvecklat ett själv som är förmöget att på ett moget sätt knyta an till nya kärleksobjekt utanför familjen. Individen befinner sig nu i ett ingenmansland där det egna självet är i obalans genom att det ömsom laddas upp till grandiosa höjder och ömsom kyls ner och i det närmaste släcks ut. Detta pendlande är en aspekt av den för denna period så typiska rörelsen mellan regression och progression. Det finns ett sug att återvända till det mycket lilla barnets sammansmältning och trygghet med en allomslutande omvärld, samtidigt finns det en "driftı att växa. Suget efter sammansmältning skapar därigenom en rädsla för att fastna $i$ ett beroendeförhållande till föräldrarna. Strävan efter frigörelse och expansion skapar också en rädsla för att inte vara förmögen att stå på egna ben. De känslor av tomhet, depersonalisering och overklighet som är kännetecknande för adolescensen måste hanteras, detta sker t.ex. genom att framställa sig själv med hjälp av estetisk praxis.

För att förstå varför det egna skapandet besitter specifika möjligheter kan vi också knyta an till den moderna psykoanalytiska diskussion som betonar narcissismens betydelse för kreativiteten och fantasin. ${ }^{18}$ En hemlighet bakom den kreativitet och fantasi som tvingar fram det egna skapande är den kontakt mellan individens medvetna och omedvetna, mellan inre och yttre värld som upprättas i regressionen.

Fantasier och dagdrömmar, som i adolescensen har en framskjuten position, har sina rottrådar djupt nedsänkta i omedvetna behov. Med denna kontaktyta utgör fantasin ett nödvändigt drivmedel för estetiska processer. Fantasin är genom sin knytning till primärprocesserna fri och oregerlig men ändå bestämd av kultur och språk. Dagdrömmar och fantasier är förborgade i den inre världen men kan t.ex. via den mänskliga kreativiteten komma till uttryck i konstnärliga produkter. Mellan de i det omedvetna grundade och icke realitetsanpassade fantasierna å ena sidan, och den socialt ac-

18 Kohut (1971, 1977), Nielsen \& Nielsen (1978), Klausmeier (1978), Solomon (1985), Frosh (1991). För Kohut, som Ziehe grundar sig på, utgör narcissismen en egen utvecklingslinje som sträcker sig från infantila former av narcissism (som är patologiska hos den vuxna individen) till mogna, produktiva och »hälsosamma" former av narcissism som kommer till uttryck i t.ex. konstnärlig verksamhet. Kohut betonar att just kreativ verksamhet fungerar som en katalysator och " transformation of narcissism" mot mer mogna former. Under optimala förutsättningar så menar han att »The deep sources of grandiosity and exihibitionism - after being appropriately aim-inhibited, tamed and neutralized - find access to and become alloyed with the reality-oriented surface aspects of the ego" (Kohut 1971). 
cepterade och efter vissa estetiska regler skapade konstnärliga produkten å andra sidan, finns ett övergångs- eller lekområde (Winnicott 1971/1981) där den skapande processen har sin motor eller utgångspunkt. $^{19}$

Att spela själv, att vara sysselsatt med estetiska praxis, handlar i stor utsträckning om utvecklandet av en kompetens att använda sig av icke-diskursiva språk. Dessa språk skiljer sig från det verbala språket som är diskursivt. Det verbala språket bärs upp av meningsbärande enheter - ord - som har bestämda betydelser. Dessa kan kombineras på en rad olika sätt men måste alltid vara linjärt, diskursivt relaterade till varandra i meningar eller satser.

Icke-diskursiva kommunikations- och uttrycksformer är däremot uppbyggda av presentativa symboler (Langer 1958). Dessa "kan inte definieras med hjälp av andra symboler på det sätt som diskursiva symboler kan" (s 120), de är bärare av upplevelseformer som inte utan vidare låter sig översättas i ord. De presentativa symbolerna wofullbordade» karaktär gör att har en innehållslig tvetydighet som gör att de förmår nå nunder« det diskursiva språket. Den amerikanska filosofen Susanne K. Langer menar att denna typ av språk bara kan förstås ngenom det helas mening, genom elementens relation inom helhetsstrukturen." (s 122) Presentativa symboler är inbegripna $i$ en semantik som vi kan kalla "framställande sym-

19 Så diskuterar t.ex. Drotner (1991) Winnicott i relation till psykoanalys och estetik i barndomen. Berg (1992) gör med utgångspunkt i en mer omfattande diskussion en genomgång av Winnicotts teorier om lek och identitetsutveckling. bolik«. Denna form av språk ligger nära de former som drömmar, fantasier och önskeföreställningar antar. Därigenom kan vi hävda att det verbala språket i första hand relateras till jaget medan det hos presentativa språk finns komponenter som gör detta speciellt lämpat att upprätta kontakt med andra, för vårt medvetande och verbalitet mer svåråtkomliga områden av den psykiska verkligheten.

Den tyske psykoanalytikern Alfred Lorenzer (1972/1975) menar att en viktig aspekt av det konstnärliga skapandet i t.ex. adolescensen är att denna verksamhet möjliggör upprättandet av förbindelser mellan de två symbolsystemen och de psykiska "nivåeru de primärt relaterar sig till. När det verbala/diskursiva språket och den realitetsanpassade omvärldsrelationen utvecklas uppstår i denna symboliseringsprocess en "rest". Socialisation innebär bortträngning, inträdet i språket tvingar barnet att reducera eller beskära de oprecisa, flytande aspekterna av omvärldsrelationen som barnet har på den outvecklade, försymboliska nivån. När barnet tillägnar sig symbolen (ordet), som utgör en del av den "symboliska ordning" vars grund är bortträngning av för kulturen hotfulla aspekter, kommer den sida som pekar mot det socialt oaccepterade, det okonventionella att hamna utanför. Som en konsekvens av denna process kommer det runt varje symbol därför att finnas ett betydelseöverskott, en krans av icke-symboliserat material. Detta bortträngda driftsbaserade "avfallsmaterial" kallar Lorenzer för protosymboler. Dessa - runt de verbala symbolerna kretsande "månringarna" - gör att språket lever och att det inte faller ihop till tomma tecken eller klichéer. Protosym- 
bolerna kan ses som språkinlärningens och socialisationsprocessens avfalls- eller slaggprodukter. Alla de verbala symboler som det lilla barnet tillägnar sig i socialisationsprocessen har växt fram ur ett vagt och mer flytande försymbol-stadium. Det är alltså inte möjligt att språkligt symbolisera allt, varje språklig symbol har så att säga en bredare referent-ram än vad den betecknar. ${ }^{20}$ Protosymbolerna utgör psykets icke-anpassade, subversiva råmaterial och fantasiproduktionens själva grundförutsättning. Utan fantasi ingen kreativitet, utan kreativitet inga estetiska processer.

Att skapa musik är att använda sig av presentativa symboler. Dessa skapas genom att "hämta näring" från lagren av bortträngda symboliska förformer - protosymbolerna. Det bortträngda sätts alltså i rörelse av de presentativa symbolerna och därigenom öppnar sig, menar Lorenzer, (1975 s 119) nya möjligheter för individens utveckling. Genom musiken "mobiliseras protosymboler som avvisats i den primära socialisationen och som nu som nya, accepterade symbolformationer upptas i den allmänna kon-

20 Saussure (1916/1970) menar att en symbol utgörs av en signifiant (det betecknande uttrycket), en signifié (det betydelse innehåll som symbolen - t.ex. ett ord - svarar mot) och en referent (det reella föremålet). Lorenzers diskussion om protosymboler har många beröringspunkter med Kristeva som utifrån begreppsparet det "semiotiska" och det "symboliska" menar att det verbala, diskursiva språket aldrig förmår lämna sitt driftbaserade ursprung. I Kristeva (1974/1984) utvecklar hon en psykolingvistik där hon med utgångspunkt i olika författarskap exemplifierar hur språkets bas i den primära narcissismens försymboliska stadium gör sig påmind och bryter fram i texten. sensenu. Att lyssna på eller att själv skapa musik gör det möjligt att förnimma och komma i kontakt med något av det som församhälleligandet trängt bort och tvingat oss att avstå från. Den estetiska självframställningen skapar därigenom $i$ adolescensens regressionsprocesser och psykiska ombrytning en möjlighet att integrera tidigare förbjudet eller bortträngt "materialk. Att som ung vara estetiskt verksam handlar därför enligt Lorenzer om alldeles speciellt goda möjligheter till en wresymboliseringsverksamhet« som därigenom också kan ge ny mening och "helau ett sårat och labilt själv. Denna "helande» funktion utgör en aspekt av den estetiska produktionens förmåga att bygga broar mellan omedvetet och medvetet. Få verksamheter kan som den estetiska självframställningen möta adolescensens regressiva behov, samtidigt som den skapar förutsättningar och möjligheter att utveckla och stärka individen. Barndomens olösta konflikter kan på detta sätt bearbetas och föras samman med nutidens krav. Denna aspekt är en viktig anledning till att estetisk praxis är av speciellt intresse för den viktiga och omfattande diskussion som handlar om ungdom och olika former av pedagogisk verksamhet. Estetisk självframställning, inte minst via musik, har genom sin kollektivitet också speciellt goda förutsättningar att gripa in i samhälleliga och kulturella förändringsprocesser. ${ }^{21}$

21 Detta diskuteras i Sernhede $(1982,1984)$ och i Fornäs, Sernhede (1983). 


\section{Senmodern adolescens, jagsvaghet och flexibel jagstyrka}

I vår tid tenderar adolescensen att sträckas ut i tiden. Det som tidigare var exklusivt adolescenta konflikter, problem och beteenden kan vi idag t.ex. se redan innan puberteten satt in. Likaså har gränsen uppåt, mot vuxenhet blivit svårare att dra. Den flexibilitet och öppenhet som är kännetecknande för denna livsfas består långt upp i vuxenlivet. Samhällets och kulturens komplexitet har gjort det omöjligt att "spika" identiteten vid utträdet ur adolescensen, identitet har blivit till ett livslångt projekt eller ett narbeter som i princip aldrig avslutas. Adolescens blir, som Julia Kristeva (1990 s 8) framhåller, "less an age category than an open psychic structure".

Den fasindelning Blos utvecklat kan ses som en beskrivning av den idealtypiska, klassiska adolescensen. Senmoderna livsvillkor tenderar att försvåra den konsolideringsprocess som Blos beskriver. När de pre-oidipala skeendena genomgår förändringar och när den oidipala situationen inte framträder på samma sätt som tidigare kommer detta också att få konsekvenser för adolescensutvecklingen. I stället för den svit fasadekvata konflikter som Blos ringar in, menar t.ex. Thomas Ziehe (1975) att det idag äger rum en överlagring av konflikterna. Bindningen till den pre-oidipala modersintrojektet (föradolescens), frigörelsen från föräldrarepresentanterna (tidig adolescens), den narcissistiska laddning av självet (egentlig adolescens) och ingående av heterosexuella relationer (senadolescens) griper i den senmoderna adolescensen in i varan- dra, allt sker sas. på en gång. Den »slutprodukt", i form av en klassisk jagstark vuxenkaraktär som Blos (1962), Erikson (1968/ 1971) och andra ser som adolescensens "kröning", uteblir i den senmoderna adolescensen. På alla de ovan angivna punkterna menar Ziehe att adolescensutvecklingen kännetecknas av en svaghetsproblematik som är relaterad till urholkning av de oidipala identifikationsprocesserna. Detta har bland annat lett till att adolescensens omtagning av den oidipala konflikten inte framträder på samma sätt som tidigare. Den moderna ungdomen har på grundval av denna utveckling av olika debattörer i det närmaste patologiserats. ${ }^{22}$

Men jag vill antyda en annan möjlighet. Måhända bidrar de ovan diskuterade överlagringarna av "uppgifterna" $i$ adolescensutvecklingen, adolescensens utsträckning $i$ tiden i kombination med den kulturella moderniseringen, till att de narcissistiska dragen och regressiva behoven blir allt mer dominerande under hela ungdomsperioden. En konsekvens av detta skulle kunna vara att de narcissistiska framträdelseformer som diskuterats i samband med ungdomskultur rent av primärt kan ses som uttryck för adolescensenta regressionsbehov. Förändringen av hela den för-oidipala perioden, av den primära narcissismen och de orala utvecklingsskeendena såväl som nedtoningen av strängheten under den anala fasen (potträning, renlighetsdressyr, aga osv.) har i kombination med urholkningen av de oidipala identifikationsprocesserna på ett nytt

22 För denna diskussion se, t.ex. Sernhede (1984), Fornäs, Lindberg \& Sernhede (1988), Frimodt (1983/1985), Alvesson (1989), Ramström (1991) 
sätt möjliggjort ett lössläppande av behov med rötter i upplevelser före språkinlärningen. Då dessa inte alltid följer en diskursivt språklig logik kommer den typ av språk som ligger till grund för de estetiska uttrycksformerna därför att ha ett företräde när det gäller att möta dessa önskningar. Detta är då en tänkbar anledning till att musik, dans, bild, teater och den egna kroppen hamnat $i$ centrum för ungas intresse $i$ vår tid, men av detta följer inte med nödvändighet att vi entydigt har att göra med en narcissistsik behovsstruktur och en jagsvaghet som brottas med oförmågan att handla, som har svårt att intressera sig för och orientera sig i sin omvärld, som vänder samhället ryggen, är avpolitiserad och vill bli lämnad ifred osv.. De traditionella formerna för rigid jagstyrka är otidsenliga och blir allt svårare att finna exempel på. Istället ter det sig som det hos dagens unga finns en förmåga att härbärgera behov av sammansmältning och extatisk utlevelse samtidigt som man är ansvarsmedveten och är beredd att göra uppoffringar förutsatt att de är meningsfulla (inte bara från de egna behovens utgångspunkt).

Den "nya narcissismen" hos dagens unga är kanske inte ett så entydigt personlighetsmönster, åtminstone tycks det inte i alla sociala miljöer vara så djupt liggande som Ziehe tycks mena. ${ }^{23}$ Den relativa frånvaron av de traditionella formerna för de oidipala skeendena har inte bara tunnat ut de identifikationsprocesser som skapade lydighet mot auktoriteter, artighet, stark pliktkänsla, beredskap att offra sig för "saken" osv.. När den överjagscensur och skuldproblematik, som tidigare var knutet till förbjudna önskningar, tonats ned har detta skapat en ny öp- penhet och en friare relation till »det-impulser" som trots allt kan hanteras av ett jag som visserligen inte visar upp de traditionella formerna för jagstyrka men inte heller kan ses som jagsvagt i klassisk mening. Dessa det-impulser kommer snarare till uttryck i icke diskursiva former. Detta är då en anledning till att estetisk praxis är av så avgörande betydelse för dagens unga. Min uppfattning är att denna kunskap har ett alledeles för litet inflytande på det sociala arbetet och den pedagogik som riktar sig till unga i vårt land. Pedagoger av alla slag måste utveckla en större förståelse för de nya icke-verbala språk som utvecklas i dagens ungdomskultur. Utan en känslighet inför de behov och den språkligt-symboliska värld som är de ungas har en pedagogik med frigörande ambitioner och ansatser små möjligheter att utvecklas.

23 Kohut (1977/1986), Psyke \& Logos nr 1 1983, Frimodt (1983/1985), Möller (1983), Ramström (1991) är några av de som diskuterat de narcisstiska komponenterna i de senaste årtiondenas personlighetsmönster. Alla är långtifrån eniga om att de narcissistiska tendenser vi kan iaktta på nyt-planetu har sin rot i en förändrad primärnarcissistisk utveckling och en ny behovsstruktur. De nya mönster vi kan se är uttryck för nya former av försvarstrategier som är betingade av förändringar i sociala och kulturella vilkor. Alvesson (1989)är en av de få som empiriskt försökt visa på en ökad förekomst av narcissistiska personlighetsstörningar i klinisk verksamhet. 


\section{Referenser}

Alvesson, Mats (1989): Sociala störningar av självet. Om den narcissistiska karaktärsstörningens utbredning, Stockholm: Studentlitteratur.

Baacke, Dieter (1968): Beat - die sprachlose Opposition, München: Juventa.

Baudrillard, Jean (1985/1987): „Kommunikationens extas", i Res Publika, nr 8.

Benjamin, Walter (1969): Bild och dialektik, Lund: Cavefors.

Bjurström, Erling (1993): Spelar rocken nägon roll?, Stockholm: Statens Ungdomsråd.

Blos, Peter (1962): On adolescence. A psychoanalytic interpretation, New York: The Free Press.

Blos, Peter (1967): »The second individuation process of adolescence», i Psychoanalytic study of the child, $\mathrm{nr} 22$.

Blos, Peter (1979): The adolescent passage, New York: International University Press.

Börjeson, Bengt (1974): Samtal med K- en bok om identiteten, Stockholm: AWE/ Gebers

Czaplicka, Magdalena (1987): Tonåringar och fritid. Hur skolungdomar använder sin tid, Stockholm: Konsumentverket.

Dahmer, Helmut (1973/1977): Psykoanalysen som samhällsvetenskap. Studier över Freud och den freudisanska vänstern, Lund: Bo Cavefors.

Drotner, Kirsten (1991): At skabe sig - selv, København: Gyldendahl.

Ehn, Billy \& Orvar Löfgren (1982): Kulturanalys, Stockholm: Liber.

Erikson, Erik H (1968/1971): Ungdomens identitetskriser, Stockholm: Natur och Kultur.

Fairbairn, W Ronald D (1940/1986): "Schizoid factors in the personality", i Psychoanalytic studies of the personality, London: Tavistock/Routledge.

Featherstone, Mike (1994): Kultur, kropp och konsumtion, Stockholm/Stehag: Symposion.

Fornäs, Johan \& Sernhede, Ove (19??): „Rockens Roll - om rockmusik och socialpedagogik", Nordisk Forum 42, 43.

Fornäs, Johan, Lindberg, Ulf \& Sernhede, Ove (1988): Under Rocken. Musikens roll i tre unga band, Stockholm: Sympision förlag.

Fornäs, Johan, Ulf Lindberg \& Ove Sernhede
(1990): Speglad ungdom, Stockholm/Lund: Symposion.

Fornäs, Johan (1991): "Narcissus och det Andra", i Johan Fornäs, Ulf Boëthius \& Sabina Cwejman (red): Kön och identitet i förändring. FUS-rapport nr 3. Stockholm/Stehag: Symposion.

Fornäs, Johan (1992): „Navigationer på kulturfloden", i Johan Fornäs m.fl. (red): Unga stilar och uttrycksformer. FUS-Rapport nr 4, Stockholm/ Stehag: Symposion.

Freud, Sigmund (1900/1958): Drömtydning, Stockholm: Aldus.

Friedman, Jonathan (1994): „Modernitetens implosion", i Oscar Hemer (red): Kulturen i den globala byn, Lund: Ægis Förlag.

Frimodt, Jens (1983/1985): Narcissism: Freud, Kohut, Ziehe, Göteborg: Vinga Press.

Giddens, Anthony (1991): Modernity and selfidentity. Self and society in the late modern age, Cambridge: Polity Press.

Grossberg, Lawrence, Cary Nelson \& Paula Treichler (1992): Cultural Studies, London: Routledge

Habermas, Jürgen (1973/1975): Legitimationsproblemer i senkapitalismen, København: Fremad.

Habermas, Jürgen (1976/1990): „Moralutveckling och jagidentitet", i Jürgen Habermas Kommunikativt handlande. Texter om spräk, rationalitet och samhälle. Göteborg: Daidalos.

Hartwig, Helmut (1980): Jugendkultur. Ästätische Praxis in der Pubertät, Hamburg: Rowohlt.

Johansson, Thomas (1994): „Narcissm, fragmentering och ontologisk trygghet", i Fornäs, Boëthius m.fl. (1994a).

Kaplan, Louise J (1984/1987): Farväl till barndomen. En bok om adolescensen, Stockholm: Natur och Kultur.

Kohut, Heinz (1971): The analysis of the self. A systematic approach to the psychoanalytic treatment of narcissistic personality disorders, New York: International University Press.

Kohut, Heinz (1977/1986): Att bygga upp självet, Stockholm: Natur och Kultur.

Kris, Ernst (1952): Psychoanalytical explorations in art, New York: International University Press. 
Kristeva, Julia (1974/1984): Revolution in poetic language, New York: Columbia University Press.

Kristeva, Julia (1986): „Från en identitet till en annan", i Lars Nylander (red): Litteratur och psykoanalys - en antologi om modern psykoanalytisk litteraturtolkning, Stockholm: Norstedts.

Kristeva, Julia (1990): »The adolescent novel ", i John Fletcher \& Anrew Benjamin (eds): Abjection, melancholia and love, London: Routledge.

Lacan, Jacques(1966/1989): „Spegelstadiet», i Ecrits, Stockholm: Natur och Kultur.

Langer, Susanne K (1942/1958): Filosofi i en ny tonart, Stockholm: Almqvist \& Wiksell /Geber.

Laing, Ronald (1960/1968): Det kluvna jaget, Stockholm: Aldus.

Lorenzer, Alfred (1972/1976): En materialistisk socialisationsteori, Östervåla: Gidlunds.

Mahler, Margret S, Fred Pine \& Anni Bergman (1975/1984): Barnets psykiska födelse. Symbios och individuation, Stockholm: Natur och Kultur.

Mangs, Karin \& Barbro Martell (1982): 0-20 år i psykoanalytiskt perspektiv, Lund: Studentlitteratur.

Möller, Marchen (1983): Narcissisme - sygdom eller skaelsord, København: Dansk psykologisk förlag.

Nielsen, Elo (1981): Narcissismen og den nye socialkarakter, Psykologilæreruddannelsen ved Roskilde Universitetscenter.

Nielsen, Elo (1984): "Narcissism och rockmusik", i Fornäs, Lindberg \& Sernhede (red): Ungdomskultur: Identitet och motstaind, Stockholm: Akademilitteratur.

Nørregaard-Frandsen, Johstein, Jørgen Gleerup \& Erling Peterson (1982): „Erfaringer i klemme», i
Bidrag, nr 16.

Ramström, Jan (1991): Tonåringen i välff̈rdssamhället, Lund: Natur och Kultur.

Sausssure, Ferdind de (1916/1970): Kurs i allmän lingvistik, Lund: Cavefors.

Sernhede, Ove (1982): „Låt tusen Stenar Rulla» i KRUT, $\mathrm{nr} 26$.

Sernhede, Ove (1984): Av drömmar väver man... Om ungdomskultur, socialisation och ungdomsarbete, Stockholm / Malmö: Socialstyrelsen/ Utbildningsproduktion.

Solomon, Robert (1985). "Creativity and normal narcissism", i Journal of creative behavior, Vol. $19 \mathrm{nr} 1$.

Winnicott, Donald W (1971/1981): Lek och verklighet, Stockholm: Natur och Kultur.

Wirth, Hans-Jürgen (1984): Die Schärfung der Sinne. Jugendprotest als persönliche und kulturelle Chance. Frankfurt am Main: Syndikat.

Ziehe, Thomas (1975): Pubertät und Narzißmus, Frankfurt am Main: Europäische Verlagsanstalt.

Ziehe, Thomas \& Herbert Stubenrauch (1982/ 1983): Ny ungdom og uscedvanlige laereprocesser, København: Politisk Revy. (Ziehes del av boken finns på svenska som $N y$ Ungdom. Om ovanliga läroprocesser, Stockholm: Norstedts 1986.)

Ziehe, Thomas (1981): „At ville elske sig selv uden at kunne", i Kontext, nr 42.

Ziehe, Thomas (1986): „Inför avmystifieringen av världen. Ungdom och kulturell modernisering", i Michael Löfgren och Anders Molander (red): Postmoderna tider? Stockholm: Norstedts.

Ziehe, Thomas (1989a): Kulturanalyser. Ungdom, utbildning, modernitet, Stockholm/ Lund: Symposion. 


\section{Summary \\ Adolescence and Aesthetic Creativity}

Why is rock so important for youth? In the everyday life of modernity cultural symbols contribute to the construction of identity. This article discuss psychological aspects of the identity work that all young people have to go through. By taking its departure in psychoanalytical theories of adolescence, and linguistic theories of symbols, the author examines how the practice of music playing and listening is related to inner, psychic processes and needs that are of crucial importance in adolescence.

There is also a brief discussion of how these processes could be related to social pedagogics. 